\title{
Occurrence of blue whales (Balaenoptera musculus) in offshore waters of southeastern Brazil
}

\author{
Alessandra Rocha ${ }^{1 *}$, Camila Marchetto ${ }^{1}$, Luiza Pacheco ${ }^{2}$ and Eduardo Resende Secchi ${ }^{3}$
}

\begin{abstract}
At-sea sightings of blue whales, Balaenoptera musculus, in Brazil are rare. A mother-calf pair was observed in deep

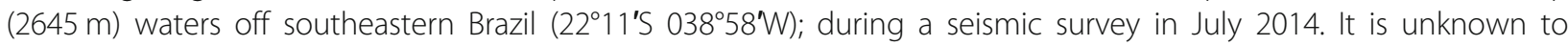
which of the subspecies the animals sighted belong. The presence of a calf suggests that blue whales use deep waters off Brazil as calving or nursing grounds. The identification and conservation of wintering grounds for blue whale populations is important to promote the recovery of blue whales as their numbers were critically reduced as a result of commercial whaling.
\end{abstract}

Keywords: Southwestern Atlantic Ocean, Brazil, Wintering ground, Distribution

\section{Background}

Blue whales (Balaenoptera musculus) were abundant in the Southern Hemisphere prior to commercial whaling, which began in the early twentieth century. Three subspecies of blue whales are recognized in the Southern Hemisphere: the pygmy blue whale (B. m. brevicauda), the Antarctic blue whale (B. m. intermedia) and an unnamed subspecies referred to as the Chilean blue whale (Committee on Taxonomy 2017). Due to the comparatively small historical catches outside the Antarctic and the observed number of pygmy and Chilean blue whales, at least in some areas of their ranges (Williams et al. 2011), these subspecies appear to be less depleted than the Antarctic subspecies, which was primary target of the commercial whaling industry and is still listed as 'Critically Endangered' (IUCN (International Union for Conservation of Nature) 2017).

Despite have been fully protected from commercial whaling for several decades, blue whale numbers globally remain low and the recovery process appears slow (Branch et al. 2004; Branch et al. 2007). Recovery of blue whales ranks high among global priorities for baleen whale conservation (Thomas et al. 2016) and could have

\footnotetext{
* Correspondence: emaildaalessandra@gmail.com

${ }^{1}$ Ekman Serviços Ambientais e Oceanográficos LTDA, Av. das Américas 700, Bloco 2 - Sala 317, Barra da Tijuca -, Rio de Janeiro-RJ CEP: 22640-100, Brazil Full list of author information is available at the end of the article
}

important implications not only for maintaining biodiversity but also for ensuring ecosystem integrity and functionality (Roman et al. 2014).

In some areas, blue whales are difficult to study in view of their low abundance and tendency to remain in deep offshore waters (Reeves et al. 2004). Little is known about the biogeography and life strategies of Southern Hemisphere blue whales. Outside Antarctic waters, only a few consistent occurrence areas are known (e.g. Hucke-Gaete et al. 2004; Branch et al. 2007; Double et al. 2014).

Although there have been progresses to understand winter distribution and migration patterns of the Southern Hemisphere blue whale in the Indian and Pacific Oceans (Double et al. 2014; Torres-Florez et al. 2015; Balcazar et al. 2016; LeDuc et al. 2017; Attard et al. 2018; Hucke-Gaete et al. 2018) very little is known in the Atlantic.

In contrast to the common occurrence of blue whales on the Pacific side of South America (Hucke-Gaete et al. 2004; Torres-Florez et al. 2014; Vernazzani et al. 2017), the species seems to be rare on the Atlantic side (Williamson 1975; Zerbini et al. 1997; Branch et al. 2007). According to Branch et al. (2007), the western South Atlantic has the lowest numbers of catches, sightings and strandings of blue whales in the Southern Hemisphere. Although a fossil blue whale was recently found in southeastern Brazil (Buchmann et al. 2017), in

(C) The Author(s). 2019 Open Access This article is distributed under the terms of the Creative Commons Attribution 4.0 International License (http://creativecommons.org/licenses/by/4.0/), which permits unrestricted use, distribution, and reproduction in any medium, provided you give appropriate credit to the original author(s) and the source, provide a link to the Creative Commons license, and indicate if changes were made. The Creative Commons Public Domain Dedication waiver (http://creativecommons.org/publicdomain/zero/1.0/) applies to the data made available in this article, unless otherwise stated. 
the 1940s and 1960s only three blue whales were captured on the whaling grounds off northeastern and southeastern Brazil, in spite of the fact that they would have been prime targets and were not yet legally protected (da Rocha 1983; Zerbini et al. 1997) and between 1966 and 1981, three sightings were recorded during whaling operations off northeastern Brazil (da Rocha 1983). On $29^{\text {th }}$ of April, 1992, a $23 \mathrm{~m}$ female stranded alive on the southernmost coast of Brazil $\left(33^{\circ} 45^{\prime} \mathrm{S}\right)$. This is the only confirmed stranding record for the species along the entire $>8,000 \mathrm{~km}$ long Brazilian coast (Dalla and Secchi 1997). Recently, in the $27^{\text {th }}$ and $31^{\text {st }}$ of July 2011, two mother-calf pairs of blue whales were observed in Potiguar Basin, northeastern Brazil (04.42' S, $036^{\circ} 40^{\prime} \mathrm{W}$ ) (de Oliveira 2015). Here, we report a new sighting in the offshore waters of southeastern, Brazil.

\section{Results}

On $3^{\text {rd }}$ of July 2014 a mother-calf pair of blue whales was observed in the offshore waters of southeastern Brazil $\left(22^{\circ} 11^{\prime} \mathrm{S}, 038^{\circ} 58^{\prime} \mathrm{W}\right.$ ) (Fig. 1) by the Marine Mammal Observer team (MMOs) aboard the seismic vessel $\mathrm{M} / \mathrm{V}$ Oceanic Champion. The sighting occurred while the vessel was in transit. The whales were traveling along the same course as the vessel $\left(150^{\circ}\right.$ heading) at $2645 \mathrm{~m}$ deep (Fig. 2). The blue whales could not be identified to the subspecies, as they are difficult to distinguish in the field (Torres-Florez et al. 2015).

\section{Discussion}

The scarcity of sighting and stranding records along the Brazilian coast is probably due to a combination of factors. Blue whale populations in the Southern Hemisphere were depleted by commercial whaling (IWC (International Whaling Commission) 2006) and their numbers have yet to recover (Branch et al. 2004; Branch et al. 2007). Furthermore, the species tends to inhabit deep offshore waters during the breeding season (Double et al. 2014; Torres-Florez et al. 2015; Lesage et al. 2017; Hucke-Gaete et al. 2018) and the limited cetacean-oriented survey efforts in deep waters of the western South Atlantic (e.g. Di Tullio et al. 2016) translates in few chances of blue whale encounters.

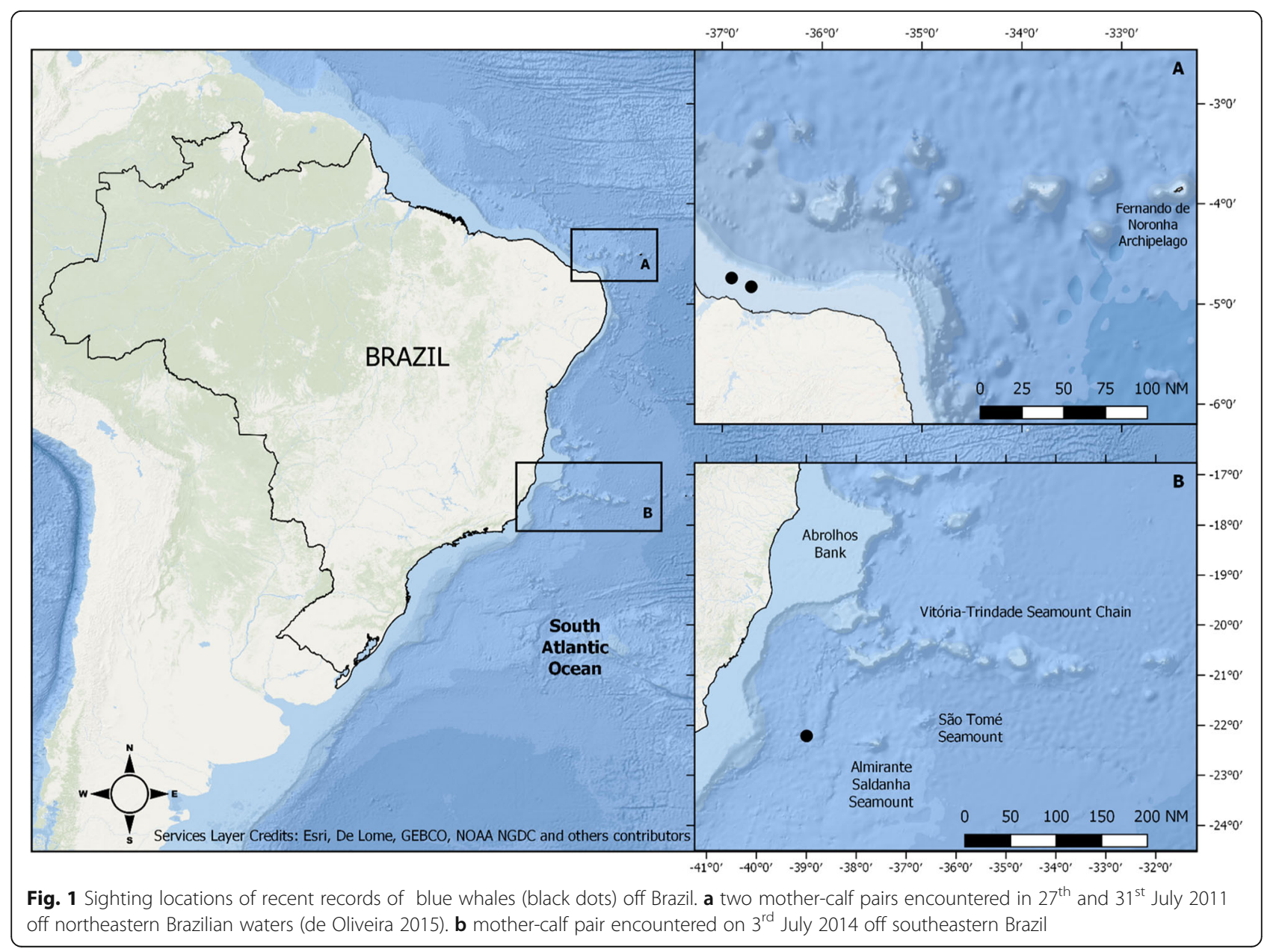




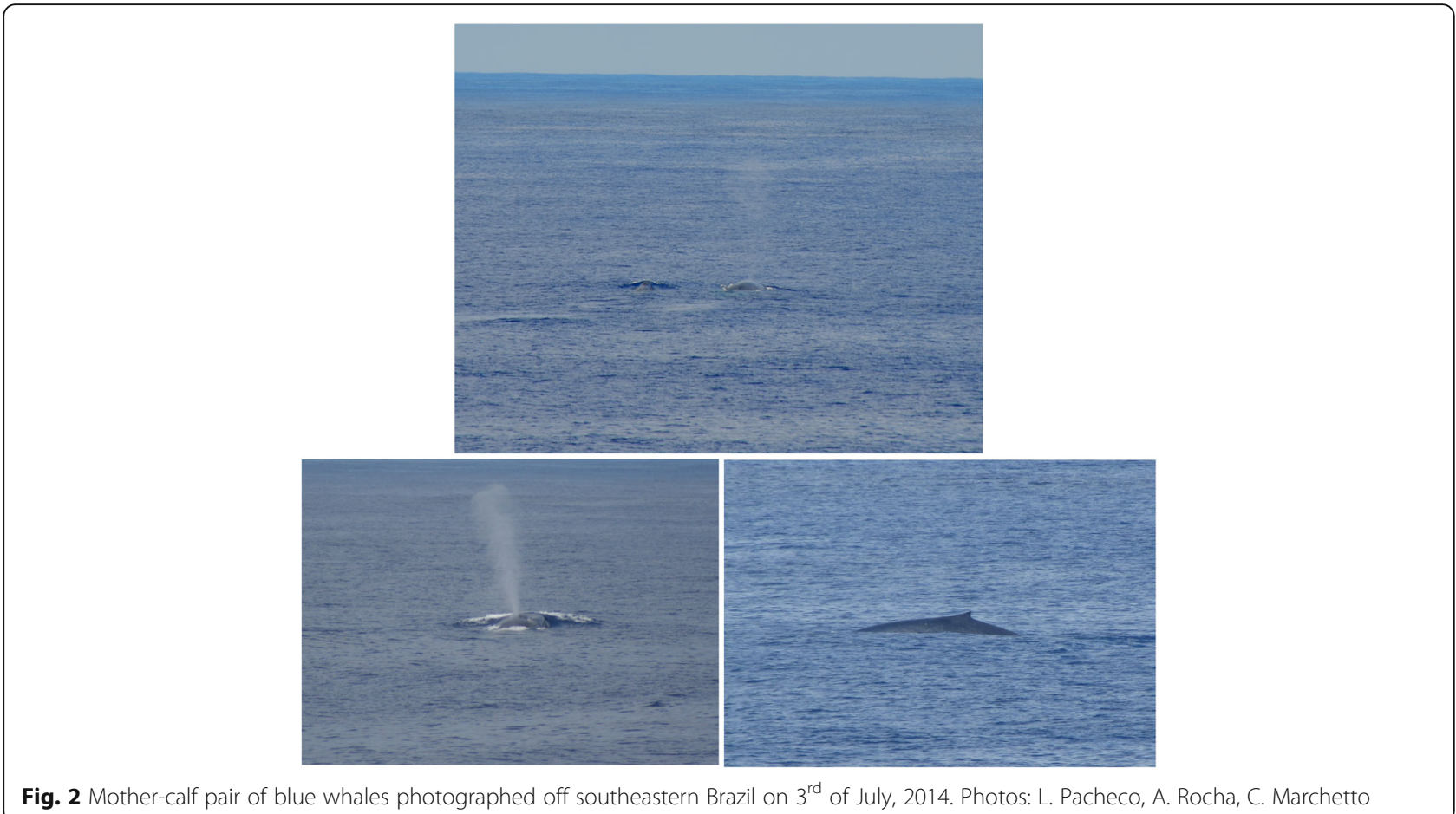

Indirect evidence suggests that the whales observed in July 2014 were Antarctic blue whales. Relatively large catches of Antarctic blue whales were made in the eastern Atlantic Ocean in winter during the whaling period (Mackintosh et al. 1929; Branch et al. 2007). Furthermore, the year-round acoustic recordings of Antarctic blue whales off Namibia, with peak in June (Thomisch 2017) indicate that South Atlantic waters might represent an important overwintering habitat for the Antarctic subspecies.

Blue whale habitat can sometimes be defined in relation to that of their principal prey, euphausiids, and to particular oceanic features (such as up-welled modified waters) and topographic features (such as ocean seamounts, coastal shelf and slope areas) (Reilly and Thayer 1990; Branch et al. 2007). The Vitória-Trindade Seamount chain off Brazil is known to have high aggregate production of phytoplankton and zooplankton (Gaeta et al. 1999; Genin 2004). Our sighting was in the vicinity of the Almirante Saldanha Seamount (c. $75 \mathrm{~nm}$ distant) and of the Vitória-Trindade Seamount Chain (c. 100nm distant) (Fig. 1). Such highly productive seamounts of the South Atlantic can provide feeding opportunities and therefore constitute important blue whale habitats. Previous surveys along the Vitória-Trindade Seamount chain have recorded fin (Balaenoptera physalus), Antarctic minke (B. bonaerensis), humpback whales (Megaptera novaeangliae) (Zerbini et al. 2011; Wedekin et al. 2014; Bittencourt et al. 2016) and also mother-calf pairs of sei whales (Balaenoptera borealis) (Heissler et al. 2016).
The mother-calf pairs of blue whales observed off northeastern Brazil (de Oliveira 2015) (Fig. 1) were close to the shelf break, and in the vicinity of deep ocean structures, a suitable environment for the euphausiid aggregation (Genin 2004; Lesage et al. 2017). Mother-calf pairs of humpback whales have been recorded along the Potiguar basin (de Oliveira 2015) and the waters off northeastern Brazil have been considered a breeding ground for minke whales (Andriolo et al. 2010).

These recent records of mother-calf pairs of blue whales off Brazil suggest that deep waters of the western South Atlantic Ocean are used for nursing by a slowly recovering population. Further studies in offshore waters along the Brazilian coast are essential for a better understanding of blue whale ecology. Identification and conservation of the areas used by blue whales are fundamental for improving their chances of recovery from the depletion that is the legacy of commercial whaling. Nevertheless, blue whales may face other challenges such as entanglement in fishing gear (Reeves et al. 1998), ship strikes (de Vos et al. 2013; Brownell et al. 2014; Rockwood et al. 2017), noise disturbance (Di Iorio and Clark 2010; Martins et al. 2013), to name a few.

\section{Acknowledgements}

We are grateful to the crew onboard MN Oceanic Champion vessel and onshore environmental team of Ekman Serviços Ambientais e

Oceanográficos Ltd (especially M. Rahy, J. de Carvalho and I. Mizutori), Gardline Marine Science do Brasil S.A. and CGG Veritas. Thanks to N.W.

Daudt, M.S. Perez, F. Flores and anonymous reviewers for theirs comments on a previous draft of this manuscript. A special thanks to Cristiane Cavalcante de Albuquerque Martins, Randall Reeves and James Gilpatrick Jr. 
who provided useful suggestions to improve the manuscript. The National Council for Research and Development-CNPq provided research fellowship to ERS. (PQ 307846/2014-8). This work is a contribution of the research group Ecologia e Conservação da Megafauna Marinha-EcoMega/CNPq.

\section{Availability of data and materials}

The datasets used and/or analyzed during the current study are available from the corresponding author on reasonable request.

\section{Authors' contributions}

AR, CM and LP were the Marine Mammals Observers (MMOs) on duty at the time of sighting. AR defined the scope and coordinated the draft of the manuscript. ERS reviewed the manuscript and helped with the identification of the blue whales. All authors read and approved the final manuscript.

\section{Ethics approval and consent to participate}

Not applicable.

\section{Consent for publication}

Not applicable.

\section{Competing interests}

The authors declare that they have no competing interests.

\section{Publisher's Note}

Springer Nature remains neutral with regard to jurisdictional claims in published maps and institutional affiliations.

\section{Author details}

${ }^{1}$ Ekman Serviços Ambientais e Oceanográficos LTDA, Av. das Américas 700, Bloco 2 - Sala 317, Barra da Tijuca -, Rio de Janeiro-RJ CEP: 22640-100, Brazil. ${ }^{2}$ Aloha Nui Gestão e Treinamentos, Rua Reverendo Gelson dos Santos Castro, 577, Florianópolis-SC CEP: 88048-340, Brazil. ²Laboratório de Ecologia e Conservação da Megafauna Marinha - EcoMega, Instituto de Oceanografia, Universidade Federal do Rio Grande/FURG, Cx.P. 474, Rio Grande-RS, Brazil.

\section{Received: 15 March 2018 Accepted: 10 February 2019}

Published online: 20 February 2019

\section{References}

Andriolo A, da Rocha JM, Zerbini AN, Simões-Lopes PC, Moreno IB, Lucena A, et al. Distribution and relative abundance of large whales in a former whaling ground off eastern South America. Zool. 2010;27(5):741-50. https://doi.org/ 10.1590/S1984-46702010000500011.

Attard CRM, Beheregaray LB, Sandoval-Castillo J, Jenner KCS, Gill PC, Jenner M$\mathrm{NM}$, et al. From conservation genetics to conservation genomics: a genomewide assessment of blue whales (Balaenoptera musculus) in Australian feeding aggregations. R Soc Open Sci. 2018:5:170925. https://doi.org/10. 1098/rsos.170925

Balcazar NE, Klinck H, Nieurkirk SL, Mellinger DK, Klinck K, Dziak RP, et al. Using calls as an indicator for Antarctic blue whale occurence and distribution across the south West Pacific and southeast Indian oceans. Mar Mamm Sci. 2016:1-15. https://doi.org/10.1111/mms.12373.

Bittencourt L, Barbosa M, Secchi E, Azevedo A. Acoustic habitat of an oceanic archipelago in the southwestern Atlantic. Deep Res Part I Oceanogr Res Pap. 2016;115:103-11. https://doi.org/10.1111/j.1365-2907.2007.00106.x/full.

Branch T, Stafford KM, Palacios DM, Bannister JL, Burton CLK, et al. Past and present distribution, densities and movements of blue whales Balaenoptera musculus in the southern hemisphere and northern Indian Ocean. Mammal Rev. 2007;37(2):116-75.

Branch TA, Matsuoka K, Miyashita T. Evidence for increases in Antarctic blue whales based on bayesian modelling. Mar Mammal Sci. 2004;20:726-54 https://doi.org/10.1111/j.1748-7692.2004.tb01190.x.

Brownell RL, Cabrera E, Vernazzani BG. Dead blue whale in Puerto Montt, Chile: Another case of ship collision mortality. Paper SC/65b/HIM08 presented to the IWC Scientific Committee; 2014. p. 9. Available on https://archive.iwc.int/.

Buchmann FS, Zurlo FM, Vannucchi FS, de Albuquerque Martins CC. First record of a fossil blue whale in São Paulo state, Brazil. Aquat Mamm. 2017:43(6):64954. https://doi.org/10.1578/AM.43.6.2017.649.

Committee on Taxonomy. List of marine mammal species and subspecies. Society for Marine Mammalogy. https://www.marinemammalscience.org/ species-information/list-marine-mammal-species-subspecies/. Consulted on 9 Feb 2019.

da Rocha JM. Revision of Brazilian whaling data. Rep Int Whaling Commission. 1983;33:419-27.

Dalla RL, Secchi ER. Stranding of a blue whale (Balaenoptera musculus) in southern Brazil: 'true' or pygmy? Rep Int Whaling Commission. 1997;47:425-30.

de Oliveira ITG. Diversidade e comportamento de cetáceos associado a embarcações na Bacia de Potiguar, Rio Grande do Norte - Brasil. Master Thesis. Natal: Federal University of Rio Grande do Norte/UFRN; 2015. p. 45.

de Vos A,Wu T, Brownell Jr. RL. Recent blue whale deaths due to ship strikes around Sri Lanka. Paper SC/65a/HIM03 submitted to the IWC Scientific Committee 2013 (unpublished). Available from the International Whaling Commission Secretariat, Cambridge, U.K.

Di lorio L, Clark CW. 2010. Exposure to seismic survey alters blue whale acoustic communication. Biol. Lett. 2010;6(1):51-4. https://doi.org/10.1098/rsbl.2009.0651.

Di Tullio JC, Gandra TBR, Zerbini AN, Secchi ER. Diversity and distribution patterns of cetaceans in the subtropical southwestern Atlantic outer continental shelf and slope. PLoS One. 2016;11(5):e0155841. https://doi.org/10.1371/journal. pone.0155841.

Double MC, Andrews-Goff V, Jenner KCS, Jenner M, Laverick SM, Brach TA, et al. Migratory movements of pygmy blue whales (Balaenoptera musculus brevicauda) between Australia and Indonesia as revealed by satellite telemetry. PLoS One. 2014;9:e93578. https://doi.org/10.1371/journal.pone.0093578.

Gaeta AS, Lorenzetti JA, Miranda LB, Susini-Ribeiro SMM, Pompeu M, Araújo CES. The Victoria Eddy and its relation to the phytoplankton biomass and primary productivity during the austral fall of 1995. Arch Fish Mar Res. 1999;47:253-70.

Genin A. Bio-physical coupling in the formation of zooplankton and fish aggregations over abrupt topographies. J Mar Syst. 2004;50(1-2):3-20.

Heissler VL, Amaral KB, Serpa N, Frainer G, Siciliano S, Secchi ER, Moreno IB. Sei whales, Balaenoptera borealis, in the South-Western Atlantic Ocean: the discovery of a calving ground in Brazilian waters. 66th International Whaling Commission Meeting, Oct. 20-28. Portoroz; 2016. Technical Document SC/ $66 \mathrm{~b} / \mathrm{SH} 20$. Available on https://archive.iwc.int/.

Hucke-Gaete R, Bedrinaña-Romano L, Viddi FA, Ruiz JE, Torres-Florez JP, Zerbini AN. From Chilean Patagonia to Galapagos, Ecuador: novel insights on blue whale migratory pathways along the Eastern South Pacific. PeerJ. 2018;6: e4695. https://doi.org/10.7717/peerj.4695.

Hucke-Gaete R, Osman LP, Moreno CA, Findlay KP, Ljungblad DK. Discovery of a blue whale feeding and nursing ground in southern Chile. Proc R Soc B Biol Sci. 2004:271(Suppl_4):S170-3. https://doi.org/10.1098/rsbl.2003.0132.

IUCN (International Union for Conservation of Nature). "The IUCN Red List of Threatened Species" Version 2017-2. http://www.iucnredlist.org. Downloaded 23 Nov 2017.

IWC (International Whaling Commission). The IWC Summary Catch Database .2006.

LeDuc RG, Archer Fl, Lang AR, Martien KK, Hancock-Hanser B, Torres-Flores JP, et al. Genetic variation in blue whales in the eastern pacific: implication for taxonomy and use of common wintering grounds. Mol Ecol. 2017;26:740-51. https://doi.org/10.1111/mec.13940.

Lesage V, Gavrilchuk K, Andrews RD, Sears R. Foraging areas, migratory movements and winter destinations of blue whales from the western North Atlantic. Endanger Species Res. 2017;34:27-43. https://doi.org/10.3354/esr00838.

Mackintosh NA, Wheeler JFG, Clowes AJ. Southern blue and fin whale. Discov Rep. 1929;: :257-540.

Martins CCA, Andriolo A, Engel MH, Kinas PG, Saito CH. Identifying priority areas for humpback whale conservation at eastern Brazilian coast. Ocean Coast Manag. 2013;75:63-71.

Reeves RR, Clapham PJ, Brownell RL, Silber GK. Recovery Plan for The Blue Whale (Balaenoptera musculus): Publications, Agencies and Staff of the U.S. Department of Commerce; 1998. p. 118. Available on https:// digitalcommons.unl.edu/usdeptcommercepub/118/.

Reeves RR, Smith TD, Josephson EA, Clapham PJ, Woolmer G. Historical observations of humpback and blue whales in the North Atlantic Ocean: clues to migratory routes and possibly additional feeding grounds. Mar Mammal Sci. 2004;20(4): 774-86. https://doi.org/10.1111/j.1748-7692.2004.tb01192.x.

Reilly S, Thayer V. Blue whale (Balaenoptera musculus) distribution in the eastern tropical Pacific. Mar Mammal Sci. 1990;6(4):265-77. https://doi.org/10.1111/j. 1748-7692.1990.tb00357.x/abstract.

Rockwood RC, Calambokidis J, Jahncke J. High mortality of blue, humpback and fin whales from modeling of vessel collisions on the U.S. West Coast suggests population impacts and insufficient protection. PLoS One. 2017; 12(8):e018052. https://doi.org/10.1371/journal.pone.0183052. 
Roman J, Estes JA, Morissette L, Smith C, Costa D, McCarthy J, et al. Whales as marine ecosystem engineers. Front Ecol Environ. 2014;12(7):377-85.

Thomas PO, Reeves RR, Brownell RL. Status of the world's baleen whales. Mar Mammal Sci. 2016;32(2):682-734. https://doi.org/10.1111/mms.12281.

Thomisch K. Distribution patterns and migratory behavior of Antarctic blue whales. Berichte zur Polar- und Meeresforsch. 2017;707:1-194.

Torres-Florez JP, Hucke-Gaete R, Leduc R, Lang A, Taylor B, Pimper LE, et al. Blue whale population structure along the eastern South Pacific Ocean: evidence of more than one population. Mol Ecol. 2014;23(24):5998-6010. https://doi. org/10.1111/mec.12990.

Torres-Florez JP, Olson PA, Bedriñana-Romano L, Rosenbaum H, Ruiz J, LeDuc R, et al. First documented migratory destination for eastern South Pacific blue whales. Mar Mammal Sci. 2015;31(4):1580-6. https://doi.org/10.1111/mms.12239.

Vernazzani BG, Jackson JA, Cabrera E, Carlson CA, Brownell RL. Estimates of abundance and trend of Chilean blue whales off Isla de Chiloe Chile. PLoS One. 2017;12(1):e0168646. https://doi.org/10.1371/journal.pone.0168646.

Wedekin LL, Rossi-Santos MR, Baracho C, Cypriano-Souza AL, Simões-Lopes PC Cetacean records along a coastal-offshore gradient in the Vitória- Trindade chain, western South Atlantic Ocean. Braz J Biol. 2014;74(1):137-44.

Williams RW, Hedley SL, Branch TA, Bravington MV, Zerbini AN, Findlay KP. Chilean blue whales as a case study to illustrate methods to estimate abundance and evaluate conservation status of rare species. Conserv Biol. 2011;25(3):526-35. https://doi.org/10.1111/j.1523-1739.2011.01656.x.

Williamson GR. Minke whales off Brazil. Sci Rep Whales Res Inst. 1975;27(27):37-59.

Zerbini AN, Andriolo A, Heide-Jorgensen MP, Moreira S, Pizzorno JL, Vanblaricom $\mathrm{G}$, et al. Migration and summer destinations of humpback whales (Megaptera novaeangliae) in the western South Atlantic Ocean. J Cetacean Res Manag. 2011;3(Special Issue):113-8.

Zerbini AN, Secchi ER, Siciliano S, Simões PC. A review of the occurrence and distribution of whales of the genus Balaenoptera along the Brazilian coast. Rep Int Whaling Commission. 1997:47:407-17.

Ready to submit your research? Choose BMC and benefit from:

- fast, convenient online submission

- thorough peer review by experienced researchers in your field

- rapid publication on acceptance

- support for research data, including large and complex data types

- gold Open Access which fosters wider collaboration and increased citations

- maximum visibility for your research: over $100 \mathrm{M}$ website views per year

At $\mathrm{BMC}$, research is always in progress.

Learn more biomedcentral.com/submissions 